\title{
A dialogical paradigm of power: From marginal theory to political reality
}

\author{
Kh.S. Galstyan \\ Yerevan State University, \\ 1, ul. A. Manukiana, Yerevan, 0025, Republic of Armenia
}

For citation: Galstyan Kh. S. A dialogical paradigm of power: From marginal theory to political reality. Vestnik of Saint Petersburg University. Philosophy and Conflict Studies, 2019, vol. 35, issue 4, pp. 626633. https://doi.org/10.21638/spbu17.2019.408

The article is dedicated to an analysis of various concepts of the origin, interpretation and strategies for power implementation. The main goal of the research is to identify the paradigm shifts in political theory and justify the relevance of the dialogical paradigm of power. In particular, the author discusses the sectional and non-sectional concepts of power, considers the main power implementation strategies under the prism of a dialogical paradigm. The study shows that there are a number of theories in the systemic, behavioral and relational concepts of power, which can serve as the theoretical basis for the dialogical paradigm of power. The author points to the limitedness of conflict theories of power and substantiates that under modern conditions, as a paradigm shifts, the whole philosophy of power is changing. In particular, the author considers the concept of "soft power" in the context of the dialogical paradigm of power implementation because, as a rule, a "soft power" strategy involves only peaceful means to achieve its goals. In addition, the concept of "soft power" implies a consensus between the subject and the object of power, which can be achieved through dialogical technologies of political communication. The author concludes that in connection with the formation and development of the information and communication society, the use of "hard" power strategies is significantly reduced. Additionally, the new trends of decentralization of power and a wide use of network management technologies, in turn, open up new perspectives for the implementation and application of dialogical strategies of power realization.

Keyworlds: dialogical paradigm of power, soft power strategy, hard power, dialogic communication technologies, paradigm shifts.

The issue of power occupies a central place among the problematic fields of political philosophy and other political science disciplines. In fact, power is a source of politics, the conceptual prism through which all other issues of politics are examined. This important role in the field of political science, in its turn, has attracted researchers' attention to the issues of the origin and development of power and the discovery of different mechanisms of its implementation during all periods of social and political thought. It is not by chance that there are more than 300 definitions of the phenomenon of power in political science, as well as many concepts that explain its essence and origin. At the same time, in the context of the historical evolution of the theory of the origin and interpretation of power, it is impossible to ignore certain paradigmatic shifts that have recently taken place in political science. In particular, we are talking about the theory of power, which can be called a "dialogical" concept of power. In this case, it is not sufficient to explain the phenomenon

(c) Санкт-Петербургский государственный университет, 2019 
of power as mere domination and submission, from the standpoint of the theory of resistance. The process of the realization of power actually involves more complex social relations, which require at least minimal agreement between the subject and the power object, the adoption of the right of the subject to dominate the object. In this context, the whole philosophy of power is changing, where the "dialogical" paradigm of power can definitely obtain the "right" to exist. In addition, there are concepts that can be attributed to the "dialogical" paradigm of power within all the theories of power interpretation: systemic, behavioral, and relational.

At first glance, the term "dialogical paradigm of power" may seem relative, since dialogue, however, implies the equality of parties and the communicative symmetry between them. The fact is that within the framework of the traditional understanding of power, the process of power realization cannot be implemented in the full symmetry between parties, because in the case of symmetry of the relationship between the subject and the power object, according to American representative of the theory of social exchange P. Blau, the interaction of equal forces depicts the absence of power [1, p 54], and C. Mills claims, that "When everyone is equal, politics does not exist, because politics requires subordinates and leaders" [2, p. 148].

Russian author V.Ledyaev notes that it is difficult to classify all traditional concepts of power interpretation, since they are classified on the basis of different criteria [3, p.28]. Nevertheless, according to him, in the context of a conceptual analysis of power, two main traditions are clearly observed. The first one, deriving from T. Hobbes and M. Weber, is sometimes called "sectional" or the tradition of realism, where power is defined in the form of asymmetric relations, at the same time, including real or potential conflict between people [3, p.28]. According to this approach, power relations are formed when one of the subjects gains the ability to unilaterally overcome the resistance of the other. In this case, power turns into a "zero-sum" relationship, where the growth of the power of individuals or groups, respectively, reduces the power of others. Essentially, the theory of resistance, acting within the framework of the relational concept of power is based on this approach, the theoretical substantiations of which are presented in the works of D. Carthright [4], J. French, B. Raven [5] and others. It should also be noted that there are quite a lot of conflictological definitions of the phenomenon of power in political science, which consider the existence of conflicting interests as an important precondition for the formation of power relations.

In particular, the American political scientist Robert Dahl, within the framework of the well-known definition of power (which can also be regarded as a classic example of the conflict paradigm), states that if everyone agreed on the means to achieve goals, there would be no need to change the behavior of others and, therefore, power relationships would not be formed. In his words, "A has power over B to the extent that he can get B to do something that B would not otherwise do" [6, p. 80].

H.Lasswell and A. Kaplan, approaching power from the point of view of behavioral theory, consider power as a process of influencing others and note that it is only one of the values and instruments manifested in interpersonal relations [7, p. 76]. Here, power relations are realized through the use of force in case of disobedience, since it is through sanctions that power differs from direct impact.

Unlike the previous approach, the second so called "non-sectional" tradition of power places an emphasis on the satisfaction of common interests in the process of power ac- 
tivity, rejecting the idea of a "zero sum" game [3, p. 28]. Power is considered as a collective resource, as the ability of the system to achieve social welfare. In this case, the legitimacy of power, the belonging of power to collective groups or the whole society, and not to individuals, is emphasized. Although realistic interpretations of power are more common, there are quite a few representatives from the second tradition - those who approach the issue of power from the standpoint of "variable-sum" games. We would like to specifically highlight T. Parsons [8], H. Arendt [9], M. Foucault [10], M. Crozier [11] and others.

In particular, T. Parsons criticized the traditional approach to interpreting power and believed that it was organically linked to the concept of "zero sum," where the "amount of power" was originally fixed, and, therefore the strength of one of the subjects automatically means a proportional power loss for the others [8, p. 95]. This approach, according to T. Parsons, is not so applicable to complex systems, such as the political system of society. In addition, he did not study the phenomenon of power in terms of the relational concept, i.e. considering it as a specific type of interpersonal relations, but, on the contrary, from the position of the system theory, where power was defined as the system ability to achieve collective goals [8, p. 13]. In this case, as Parsons argues, "the amount of power" does not look like a "zero sum," and its volume can be changed, for example, as in the case of crediting the economy. People "invest" their trust in those who govern, thus benefiting the power process because power provides collective goals. While T. Parsons criticizes the "zero sum" concept of power implementation, $\mathrm{H}$. Arendt disputes the asymmetric nature of power in general. She notes that a human being is a unique social layer that develops in all spheres of human life, and cannot be attributed to the individual character, as it always exists as a social one. According to $\mathrm{H}$. Arendt, power relations are formed in the process of communication between equal subjects. At the same time, the relationship between the subject and the object of power, of course, is similar to back and forth communication, which, in turn, requires that participants in communication, "speakers" and "listeners" constantly discuss and conduct dialogues. As the author is convinced, power appears when "equal people come together, which corresponds to human abilities not only to act, but also to act together" [9, p.64].

French political scientist Michel Crozier, considering power as interpersonal relations that allow one person to influence someone else's will and behavior, reveals the phenomenon of negotiations, which, in his opinion, completely transforms the meaning of power relations. As he says, when we consider power not as an individual ability of A and $\mathrm{B}$ to influence each other, but as a developing relationship between them, we discover the phenomenon of negotiations... Every phenomenon of power, regardless of its origin, degree of legitimacy, implementation mechanisms, goals and methods of achievement, always means the ability of any person or group to influence each other [11, p. 94]. Indeed, it is difficult to deny the fact that all more or less persistent lasting human relationships require a complex system of mutual contacts and adaptation. Power cannot exist by itself. As M. Crozier notes, "Power relations are established only when the parties are integrated, at least temporarily, into an organized whole" [11, p.95]. According to him, people can achieve collective goals only through the realization of power relations, and, on the contrary, the power is possible only in the process of implementing the same collective goals, which directly implies the need for negotiations [11, p. 96]. According to M. Crozier, "Power relations are mutual. And if the subject of power A can influence the behavior and actions of object B, then B, in turn, has the ability or capacity to impact A [11, p. 96]. 
Accordingly, on the basis of the well-known definition of power, given by the American political scientist Robert Dahl, he defines power as the ability or capacity of A to achieve the best results for himself through negotiations with $B$ [12, p. 84]. This approach can already be regarded as "dialogical" in its content, since Crozier's interpretation of power implies a continuous chain of negotiations between the subject and the object, where the status of political subjects and objects can constantly change. In this context, the dialogical paradigm of power achieves at least the right to exist.

At the same time, the realization of power always involves complex, concrete strategic and tactical actions. Therefore, the question may arise how applicable power strategies are in the context of the "dialogical" paradigm of power. Before answering the question, it is necessary to emphasize that the power strategy is understood as the complex of the basic means and methods which are used to achieve its goals. From this point of view, we can distinguish "soft" and "hard" strategies. If we look at the "hard" and "soft" power strategies, it is obvious that the former is completely appropriate for the conflict, and the latter fits into the framework of the "dialogical" paradigm of power.

Many authors define "hard power" as a form of political power to influence the behavior or interests of other political actors using military and or economic pressure mechanisms. For example, J. Nye defines hard power as "the ability to use the carrots and sticks of economic and military might to make others follow your will" [13]. Others define hard power as "the application of military power to meet national ends - that is, the deployment of ground troops, naval assets, and precision munitions to secure a vital national objective [14]. The "hard power" strategies are still one of the most frequently used technologies in both international and domestic policy. However, at the same time, it should be noted that some paradigmatic shift is also noticeable, especially after the $90 \mathrm{~s}$ of the $20^{\text {th }}$ century. The so-called "soft power" influence strategies are increasingly used in order to raise the legitimacy and effectiveness of authorities, to create a favorable external image of governments.

One of the first who scientifically substantiated and began to widely use the concept of "soft power" is an American scientist, professor at Harvard University J. Nye. He defines "soft power" as the ability of a country to persuade others to do what it wants without force or coercion, which can be achieved by means of persuasion and attractiveness [15]. Later, he also introduced the concept of "smart power," defining it as an effective power strategy combining the resources of "hard" and "soft" power. Of course, J. Nye also believes that "hard power" in modern international relations has never lost its key meaning, and such supranational groups, as terrorist organizations, most often resort to violence when choosing the methodology of political struggle. However, "soft power" is important for reducing the scale of terrorist actors, forming antiterrorist coalitions, as well as solving common problems that require multilateral cooperation of the states and parties [16, p. 34]. In essence, the main purpose of using the strategy of "soft power" is to provide attraction to any government. This goal can be achieved, according to the author, by using the power of information and image symbols. "Soft power" is formed under the influence of a number of factors, such as the country's culture, political values and foreign policy, which contributes to the formation of a unified value system among the main participants of interstate and intercultural communication. As a successful example, Nye mentions the implementation of the American Marshall Plan for Europe, during which the Europeans voluntarily accepted American domination [16, p.34]. In particular, after World War II, 
the United States invested billions of dollars into war-ravaged Western Europe to prevent it from falling to the influence of the Communist Soviet Union. The Marshall Plan included humanitarian aid, such as food and medical care; expert advice for rebuilding destroyed infrastructures, such as transportation and communication networks and public utilities and outright monetary grants.

Of course, the term "soft power" is a development of the American political science school, which, however, does not mean that there is only American "soft power." The same J. Nye speaks of the great potential of European "soft power," considering it as the main competitor of American "soft power" in the world. According to the American author, European culture, art and literature, music and cuisine are of great interest and favorable attitude all over the world, which makes Europe attractive from the point of view of the "soft power" concept. In addition, the softer approaches of the European foreign policy, multilateral diplomatic efforts and environmental initiatives have a positive impact on the formation of a positive image of European foreign policy. According to Nye, no European country can compete with the United States separately, but in integrity the European Union whose "soft power" is comparable to the American one, has great potential.

The Chinese strategy of "soft power," which is considered one of the most important strategic directions of the foreign policy of the current Chinese top leadership, can also compete with American soft power. In a political report published at the XVII Congress of the Chinese Communist Party, the following problems of building Chinese "soft power" were raised: 1 . create a system of key socialist values, 2 ; create a harmonious culture and cultivate a civilized moral, 3 . widely disseminate the national culture and build a common spiritual center of the Chinese nation, 4. promote innovation in culture, strengthen the vital potential of culture development [17, p. 120]. As O. Rusakova notes, the main feature of the Chinese "soft power" is the principle of harmony, which applies to all spheres of public and political life, including human nature, human society and the establishment of harmonious relations between states [17, p. 120]. According to Chinese experts, the Chinese "soft power" in domestic policy contributes to the growth of the national spirit, strengthening the collective identity of the Chinese people, the unity of the country, preservation and development of ancient Chinese culture. In foreign policy the Chinese "soft power" strategy contributes to the strengthening of the country's influence in international relations and increases mutual understanding between nations [18, p. 150]. Indeed, in the framework of cultural nature, China offers the world its own understanding of development as a separate individual, society as well as interstate and interpersonal relationships. While the American concept of soft power offers the world the so-called "American Dream," which is based on successful relations in the external life of an individual, China offers "the idea of harmonious world," which includes Daoism, Confucianism and Buddhism, in which the main emphasis is placed on achieving inner harmony, a derivative of which supports an external harmony [19].

In the Russian social and political discourse, the research on "soft power" concept has also recently intensified [20]. President of the Russian Federation Vladimir Putin spoke about this at the highest state level on July 9, 2012 during a meeting with ambassadors and permanent representatives [21]. In his speech, the Russian president noted the main priorities and problems of the state's foreign policy, inviting Russian diplomats to use "soft power" methods in their work. According to Putin, "soft power" is all about promoting one's interests and policies through persuasion and creating a positive perception 
of one's country, based not just on its material achievements but also its spiritual and intellectual heritage. As he says: "Russia's image abroad is formed not by us and as a result it is often distorted and does not reflect the real situation in our country or Russia's contribution to global civilization, science and culture. Our country's policies often suffer from a one-sided portrayal these days. Those who fire guns and launch air strikes here or there are the good guys, while those who warn of the need for restraint and dialogue are for some reason at fault. But our fault lies in our failure to adequately explain our position. This is where we have gone wrong" [21]. From this point of view, one of the most effective ways to fully utilize the potential of soft power strategy is public diplomacy, the creation of new platforms and platforms for dialogue, which implies the establishment of long-term relations and the creation of favorable conditions for the implementation of foreign policy [22, p.45]. Among such dialogue platforms created and acting on the initiative of Russia, we can mention the International Public Foundation "Dialogue of Civilizations," the Cultural-Economic Forum "East-West," "Petersburg Dialogue," "Eurasian Dialogue," A. Gorchakov Public Diplomacy fund and others [23]. In these platforms and forums current issues in international relations are discussed. According to the Russian expert E. Kochetov, these platforms form a full-fledged, highly intelligent dialogical network, the recommendations of which are taken into account by great world leaders and leading structures [24, p.68].

Thus, summing up the research, it can be stated that some paradigmatic shifts are obvious both in the concepts of power interpretation and the strategies for the realization of power. In particular, the phenomenon of power can be represented not only as a "zero sum" game, but as a "variable-sum" relationship, in the context of the dialogue paradigm, as an ongoing dialogue between the subject and the object of power. The same goes for power realization strategies. In particular, why are we inclined to present the "soft power" strategy as a dialogical one? Firstly, the government chooses exclusively peaceful measures to achieve its goals. Secondly, the concept of "soft power" implies a certain consensus between the subject and the object of power, which, most likely, can be achieved through the extensive usage of dialogical technologies of political communication. Thirdly, the soft power technologies provide a certain competition between different ideas, values and cultures, which allows subjects of interstate relations and internal political communication to choose the best ideas and concepts corresponding to their national interests. Fourth, the value expansion of "soft power" is not a forced and mandatory action, but rather is voluntary, which, in turn, has a greater potential for the legitimacy of power. In addition, corresponding with the formation and development of information and communication societies, there are some restrictions on the use of "hard" power strategies. The decentralization of power and the improvement of network management systems provide new opportunities for widespread adoption and use of dialogical strategies of power in the context of political communication. The transition to "soft" strategies for the implementation of power, especially in domestic political relations, as well as the practice of extensive use of dialogue technologies instead of monologue forms of political communication can significantly affect the speed, quality and effectiveness of democratic reforms in transit societies. As a result, already in the modern social and political relations, the dialogical concept of power acquires a new meaning and significance, and in some conditions can become the only way for humanity to coexist. 


\section{References}

1. Blau, P. (1964), Exchange and Power in Social Life, John Wiley and Sons Pub., New York.

2. Mills, C. Wright (1959), The Power Elite, Inostrannaia literatura Publ., Moscow. (In Russian)

3. Lediaev, V. (2001), A Power: conceptual analysis, ROSSPEN Publ., Moscow. (In Russian)

4. Cartwright, D. A. (1959), "Field Theoretical Conception of Power", in Cartwright, D. (ed.), Studies in Social Power, Ann Arbor Publ., Michigan, pp. 183-220.

5. French, J. and Raven, B. (1959), "The bases of social power", in Cartwright, D. (ed.), Studies in Social Power, Ann Arbor Publ., Michigan, pp. 150-167.

6. Dahl, R. (1969), The Concept of Power, Political Power: A Reader in Theory and Research, The Free Press Publ., New York.

7. Lasswell, H. and Kaplan, A. (1950), Power and Society, Yale University Press, New Haven.

8. Parsons, T. (1986), Power and the Social System, in Lukes, S. (ed.), Power, Blackwell Publ., Oxford, pp. 96-143. 76.

9. Arendt, H. (1986), Communicative Power, in Lukes, S. (ed.), Power, Blackwell Publ., Oxford, pp. 59-

10. Fuko, M. (2002), Intellectuals and Power: Selected political articles, speeches and interviews, Moscow. (In Russian)

11. Komotskii, B. (1990), Michel Crozier as a political scientist, Sotsial'no-politicheskie nauki, vol. 9, pp. 94-102. (In Russian)

12. Mshvenieradze, V. et al., (1989), Power: Essays on the modern political philosophy of the West, Nauka Publ., Moscow. (In Russian)

13. Nye, J. (2004), Power in the Global Information Age: From Realism to Globalization, Routledge Publ., London, New York.

14. Cambell, K. M. and O'Hanlon, M.E. (2006), Hard Power: The New Politics of National Security, Basic Books Publ., New York.

15. Nye, J. (2004), Soft Power: The Means to Success in World Politics, Public Affairs Publ., New York.

16. Nye, J. (2004) “'Soft power' and US-European relations”, Svobodnaia mysl' - XXI, vol. 10, pp. 104115. (In Russian)

17. Rusakova, O. (2012), Soft Power Discourse in Foreign Policy, Vestnik IuUrGU: Ser. Sotsial'no-gumanitarnye nauki, vol. 32, pp. 75-84. (In Russian)

18. Tszaitsi, L. (2009), "'Soft power" in China’s development strategy, POLIS. Politicheskie issledovaniia, vol. 4, pp. 52-59. (In Russian)

19. Chines soft power, available at: https://ukessays.com/essays/politics/chiense-soft-power.php, (accessed: 15.12.2018).

20. Ponomareva, E. (2018), Iron grip of "soft power", available at: http://www.mgimo.ru/news/experts/ document238257 (accessed: 18.11.2018). (In Russian)

21. Parshin, P. (2013), “The Problem of 'Soft Power' in Russian Foreign Policy”, Analiticheskie doklady, Tsentr global'nykh problem MGIMO Publ., vol. 36, no. 1. (In Russian)

22. Filimonov, G. Iu. (2013), "Actual issues of the strategy of 'soft power' in foreign policy of the Russian Federation", Zakon i pravo, vol. 9, pp. 9-18. (In Russian)

23. Naumov A. "'Soft power' and the foreign policy image of the Russian Federation, available at: http://www. perspektivy.info/rus/gos/magkaja_sila_i_vneshnepoliticheskij_imidzh_rossijskoj_federacii_2015-03-30. htm, (accessed: 20.12.2018). (In Russian)

24. Studneva, E. (2018), "The Foreign Ministry and the Public Chamber of Russia discussed the resources of 'soft power' 13.12.2011”, Mezhdunarodnaia zhizn', available at: http://interaffairs.ru/read.php?item=8129 (accessed: 18.12.2018). (In Russian)

Received: November 30, 2018 Accepted: June 13, 2019

Author's information:

Khachik S. Galstyan — Dr. Sci. in Political Science, Professor; khgalstyan@ysu.am 


\title{
Диалогическая парадигма власти: от маргинальной теории к политической реальности
}

\author{
Х. С. Галстян \\ Ереванский государственный университет, \\ Республика Армения, 0025, ул. А. Манукяна, 1
}

Для цитирования: Galstyan Kh.S. A dialogical paradigm of power: From marginal theory to political reality // Вестник Санкт-Петербургского университета. Философия и конфликтология. 2019. Т. 35. Вып. 4. С. 626-633. https://doi.org/10.21638/spbu17.2019.408

Статья посвящена анализу различных концепций возникновения, истолкования и стратегий реализации власти. Основная цель исследования - выявление особенностей парадигмальных сдвигов в политической теории и обоснование диалогической парадигмы власти. В частности, в статье обсуждаются традиционные (секционные) и нетрадиционные (несекционные) концепции интерпретации власти, раскрываются теоретические и концептуальные основы диалогической парадигмы власти, в свете которой и рассматриваются властные стратегии. В качестве основных методологических установок были использованы системный и сравнительный методы исследования. В первом случае феномен власти рассматривался как сложный системный организм, а с помощью второго метода были выявлены эволюционные подвижки различных концепций власти. В ходе исследования выявлено, что как в системной, так и в поведенческой и реляционной концепциях интерпретации властных взаимоотношений есть теории, которые могут служить основой диалогической парадигмы власти. Автор указывает на ограниченность конфликтологических теорий власти и обосновывает идею о том, что в современных условиях по мере парадигмальных сдвигов меняется вся философия осуществления власти. В частности, обсуждая жесткие и мягкие стратегии реализации власти, автор указывает, что понятие «мягкая сила» вполне вписывается в контекст диалоговой парадигмы власти. Дело в том, что мягкая властная стратегия предполагает только мирные средства достижения целей. Кроме того, понятие мягкой силы подразумевает консенсус между субъектом и объектом власти, которого, скорее всего, можно достичь с помощью диалоговых технологий политической коммуникации. Автор приходит к выводу, что параллельно с формированием и развитием информационного и коммуникационного общества существенно снижаются возможности использования жестких властных стратегий, а децентрализация власти и использование сетевых технологий управления, в свою очередь, открывают новые перспективы для внедрения и применения диалоговых форм коммуникации в стратегиях осуществления власти.

Ключевые слова: диалогическая парадигма власти, мягкая властная стратегия, жесткая сила, диалоговые коммуникационные технологии, парадигмальные сдвиги.

Статья поступила в редакцию 30 ноября 2018 г.; рекомендована в печать 13 июня 2019 г.

Контактная информация:

Галстян Хачик Самвелович - д-р полит. наук, проф.; khgalstyan@ysu.am 